\title{
Abnormalities in Proinsulin Processing in Islets from Individuals with Longstanding T1D
}

\author{
Emily K. Sims ${ }^{1,2}$, Julius Nyalwidhe ${ }^{6}$, Farooq Syed ${ }^{1,2}$, Henry T. Bahnson ${ }^{8}$, Leena Haataja ${ }^{9}$, Cate \\ Speake $^{8}$, Margaret A. Morris ${ }^{7}$, Raghavendra G. Mirmira ${ }^{1-5}$, Jerry Nadler ${ }^{7}$, Teresa L. \\ Mastracci $^{5,10}$, Peter Arvan $^{9}$, Carla J. Greenbaum ${ }^{8}$, and Carmella Evans-Molina ${ }^{2-5,11}$
}

From the Department of ${ }^{1}$ Pediatrics, the ${ }^{2}$ Center for Diabetes and Metabolic Diseases, the Departments of ${ }^{3}$ Cellular and Integrative Physiology, ${ }^{4}$ Medicine, and ${ }^{5}$ Biochemistry and Molecular Biology, Indiana University School of Medicine, Indianapolis, IN; and the Departments of ${ }^{6}$ Microbiology and Molecular Cell Biology and ${ }^{7}$ Internal Medicine, Eastern Virginia Medical School, Norfolk, VA; ${ }^{8}$ Diabetes Clinical Research Program, Benaroya Research Institute, Seattle Washington; ${ }^{9}$ Division of Metabolism, Endocrinology \& Diabetes, University of Michigan Medical Center, Ann Arbor, MI; ${ }^{10}$ Indiana Biosciences Research Institute, Indianapolis, IN; and the ${ }^{11}$ Roudebush VA Medical Center, Indianapolis, IN;

Correspondence: Carmella Evans-Molina, Indiana University School of Medicine, 635 Barnhill Drive MS 2031A, Indianapolis, IN, USA; Tel: (317) 274-4145, Fax: (317) 274-4107, E-mail: cevansmo@iu.edu _or Emily K. Sims 705 Riley Hospital Drive, Room 5960, Indianapolis, IN,USA; Tel: (317) 944-3889; Fax (317) 944-3882, E-mail: eksims@iu.edu

KEYWORDS: Type 1 Diabetes, proinsulin, islet, beta cell, prohormone, cytokines 


\section{ABSTRACT}

Work by our group and others has suggested that elevations in circulating proinsulin relative to C-peptide is associated with development of Type 1 diabetes (T1D). We recently described the persistence of detectable serum proinsulin in a large majority (95.9\%) of individuals with longstanding T1D, including individuals with undetectable serum C-peptide. Here we describe analyses performed on human pancreatic sections from the nPOD collection $(n=30)$ and isolated human islets $(n=10)$ to further explore mechanistic etiologies of persistent proinsulin secretion in T1D. Compared to nondiabetic controls, immunostaining among a subset (4/9) of insulin positive T1D donor islets revealed increased numbers of cells with proinsulin-enriched, insulin-poor staining. Laser capture microdissection followed by mass spectrometry revealed reductions in the proinsulin processing enzymes prohormone convertase $1 / 3(\mathrm{PC} 1 / 3)$ and carboxypeptidase $\mathrm{E}$ (CPE) in T1D donors. Twenty-four hour treatment of human islets with an inflammatory cytokine cocktail reduced mRNA expression of the processing enzymes PC1/3, PC2, and CPE. Taken together, these data provide new mechanistic insight into altered proinsulin processing in long-duration T1D and suggest that reduced $\beta$ cell prohormone processing is associated with proinflammatory cytokine-induced reductions in proinsulin processing enzyme expression.

\section{INTRODUCTION}

Type 1 diabetes (T1D) is a chronic autoimmune disease that results from immunemediated destruction of pancreatic $\beta$ cells, leading to a lifelong dependence on exogenous insulin therapy (1). Classic models of type 1 diabetes pathogenesis have suggested near complete destruction of pancreatic $\beta$ cells by the time of diagnosis (1). However, recent data from clinical cohorts of individuals with long-duration disease has shown that a significant proportion of individuals with T1D $>3$ years duration have detectable C-peptide, and that Cpeptide secretion is meal-responsive (2-5). In parallel, histologic analysis of pancreata from 
organ donors with diabetes has demonstrated the presence of insulin containing islets many years after diagnosis $(6,7)$. Together, these findings have challenged the notion that all $\beta$ cells are destroyed in diabetes, while also raising a number of questions regarding the molecular and functional phenotype of $\beta$ cells that persist in long-duration disease.

The hallmark of a healthy $\beta$ cell is efficient and robust processing of preproinsulin into mature insulin protein, which is secreted in response to nutrient stimulation. Under normal conditions, preproinsulin is converted to proinsulin following cleavage of its signal peptide by signal peptidases within the lumen of the endoplasmic reticulum (ER) (8). Proinsulin disulfide bond formation and terminal protein folding occur in the ER and Golgi apparatus, and intact proinsulin is eventually cleaved into mature insulin and C-peptide by the enzymes prohormone convertase 1/3 (PC1/3), PC2, and carboxypeptidase E (CPE) in secretory granules (8). In response to inflammatory, oxidative, and endoplasmic reticulum stress in diabetes, protein processing capacity within the secretory compartment of the $\beta$ cell can become overwhelmed. This leads to the accumulation of inadequately processed proinsulin (9) that can be detected noninvasively in the circulation by measurement of the ratio of proinsulin relative to circulating mature insulin or C-peptide, or the $\mathrm{PI}: \mathrm{C}$ ratio (10).

We recently described the persistence of detectable serum proinsulin in a majority $(95.9 \%)$ of individuals with longstanding T1D ( $\geq 3$ years) who were followed as part of the T1D Exchange Registry (11). Remarkably, this finding extended to individuals who had undetectable serum C-peptide; specifically, $89.9 \%$ of individuals without detectable stimulated serum Cpeptide had readily detectable serum proinsulin (11). Moreover, even in those with detectable C-peptide, $\mathrm{PI}: \mathrm{C}$ ratios were significantly increased compared to controls, and higher fasting $\mathrm{PI}$ :C ratios were found in individuals with the worst stimulated beta cell function (11). Intriguingly, serum proinsulin levels remained steady over 4 years of follow-up, despite continued loss of Cpeptide (11). These findings suggested that in long-duration type 1 diabetes, the ability to secrete proinsulin persists, even in individuals who no longer secrete detectable levels of serum 
C-peptide. However, the mechanistic etiologies behind these findings have not been elucidated.

In the present study, we analyzed pancreatic sections from donors with established T1D and performed in vitro analyses of cytokine treated human islets. Immunostaining analysis of pancreatic sections from T1D donors confirmed discrepancies in proinsulin and C-peptide localization at the level of the islet in some donors with longstanding T1D, while mass spectroscopy analysis of laser-captured $\beta$ cells from organ donors with diabetes suggested that defects in hormone processing may arise from impaired expression of proinsulin processing enzymes. Consistent with this, cytokine treatment of human islets was associated with reductions in mRNA levels encoding proinsulin processing enzyme. Taken together, these data highlight a prominent role for defective prohormone processing in T1D and provide novel insight into the molecular phenotype of the $\beta$ cell in longstanding disease.

\section{METHODS}

Human islet sections were obtained through the Network for Pancreatic Organ Donors with Diabetes (nPOD) (12). Sections for immunostaining were obtained from 7 nondiabetic controls and 17 donors with type 1 diabetes. Sections from donors with type 1 diabetes were selected to include a range of diabetes durations, individuals with and without detectable random C-peptide, and documented presence or absence of insulin positive islets. Three of the donors with type 1 diabetes had detectable random serum C-peptide and 13 were classified by nPOD as C-peptide negative (random serum C-peptide $<0.017 \mathrm{nmol} / \mathrm{L}$ via TOSOH immunossay) (12). One donor with type 1 diabetes did not have an available serum C-peptide value. Sections for laser capture microdissection (LCM) were obtained from 3 nondiabetic controls and 3 donors with type 1 diabetes who were known to have positive islet autoantibodies and documented presence of residual insulin positive islets (Case IDs 6234, 6238, 6271, 6212, 6245, and 6247). 
Isolated human islets from 10 nondiabetic donors were obtained from the Integrated Islet Distribution Program. Islets from each donor were treated with or without 24 hours of a cytokine

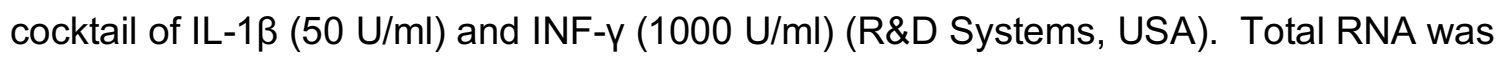
recovered using RNeasy mini kits (Qiagen, USA), reverse transcribed, and subjected to qRT-

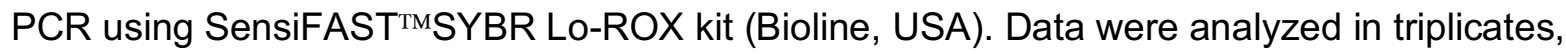
normalized to Glyceraldehyde-3-Phosphate Dehydrogenase GAPDH, and presented as fold change in expression relative to untreated islets from the same individual using the $2^{\wedge}-\Delta \Delta C T$ method. Primer sequences used were as follows.

Table 1. Primer Sequences

\begin{tabular}{|l|l|}
\hline Primer name & Primer Sequence \\
\hline Carboxypeptidase E (CPE) - Forward & CATCTCCTTCGAGTACCACCG \\
\hline CPE - Reverse & CCGTGTAAATCCTGCTGATGG \\
\hline Prohormone Convertase 1/3 (PCSK1/PC1/3) - Forward & GGACCTCTGAGTATGACCCG \\
\hline PCSK1/PC1/3 - Reverse & AGCTTTGGCATTTAGCAAGCC \\
\hline Prohormone Convertase 2 (PCSK2/PC2) - Forward & GGGAAAGGTGTTACCATTGGAA \\
\hline PCSK2/PC2 - Reverse & CCAGTCATCTGTGTACCGAGG \\
\hline $\begin{array}{l}\text { Glyceraldehyde-3-Phosphate Dehydrogenase } \\
\text { (GAPDH) - Forward }\end{array}$ & CAGCCTCAAGATCATCAGCAA \\
\hline GAPDH - Reverse & TGTGGTCATGAGTCCTTCCA \\
\hline
\end{tabular}

Immunostaining

Tissue sections were deparaffinized through graded xylene and ethanol and permeabilized in PBS containing $0.1 \%$ triton-X 100 (FisherScientific). Sections were co-stained with primary antibodies against insulin (guinea pig; 1:500 and 1:1000; Millipore) and proinsulin (mouse; 1:50 and 1:200; Developmental Studies Hybridoma Bank; detects the B-C junction of human proinsulin) as previously described and validated $(13,14)$. Antii-guinea pig Ig Alexa 647 
and anti-mouse Ig Alexa 488 secondary antibodies were used (1:400; Jackson ImmunoResearch). Images were acquired using a LSM 700 confocal microscope (Zeiss).

\section{Mass spectrometry Analysis of Laser Capture Microdissection (LCM) Islets}

As previously described, high resolution high mass accuracy label free quantitative mass spectrometry analysis was applied to islets isolated by laser capture microdissection from nPOD pancreatic sections from 3 donors with type 1 diabetes, and 3 nondiabetic controls (15). To select insulin positive islets for analysis, islets in unstained tissue sections were identified based on intrinsic autofluorescence, which has been shown to correlate with insulin staining (15).

Serial $10-\mu$ m-thick tissue sections were prepared from nPOD pancreas blocks and attached onto polyethylene naphthalate (PEN) membrane slides. The tissue sections were dehydrated with graded ethanol solutions before isolating and collecting islets on cups using an ArcturusXT TM LCM instrument (Thermo Fisher Scientific), which is equipped with dual ultraviolet (UV) and infrared (IR) lasers. The IR laser captures cells of interest, while the UV laser microdissects cells of interest and prevents any significant contamination of captured material with adjacent acinar tissue. Islets in unstained tissue sections were identified by their unique and specific intrinsic florescence behavior, which correlates with insulin staining, and was detected using triple filter upon UV illumination of the specimen $(16,17)$. Protein extraction was performed using the Liquid Tissue MS Protein Prep Kit (Expression Pathology, Rockville, MD) according to the manufacturer's protocol. Briefly, the LCM cap films containing approximately 3 $\mathrm{x} 10^{4}$ cell equivalents (estimates based on the thickness and area of the captured islet tissue) were transferred into $20 \mu \mathrm{l}$ of liquid tissue buffer in a $1.5 \mathrm{ml}$ low protein binding reaction tube and centrifuged at $10,000 \times \mathrm{g}$ for 2 minutes to pellet the film. The islet proteins were extracted by heating the mixture at $95^{\circ} \mathrm{C}$ for 90 minutes with intermittent mixing at 20 minute intervals. After 90 minutes, the samples were centrifuged at $10,000 \times \mathrm{g}$ for 1 minute before cooling in ice for $2 \mathrm{~min}$. The equivalent of 1:50 trypsin was added to the extracted protein and incubated at 
$37^{\circ} \mathrm{C}$ for 18 hours to generate tryptic peptides. After the trypsin digestion step, an aliquot of the generated peptides was used in a Micro BCA assay to determine the peptide concentrations. The remaining peptides were reduced (10mM DDT) and alkylated (35mM iodoacetamide) and stored at $-80^{\circ} \mathrm{C}$ prior to use for mass spectrometry analysis. LC-MS analysis of digested samples was conducted as previously described (18). Tryptic peptides were solubilized in normalized volumes of $0.1 \%$ formic acid $(F A) / H 2 O$ and the concentration of the digested peptides were determined a Micro BCA assay. The final concentration of the samples was adjusted to $0.5 \mu \mathrm{g} / \mu \mathrm{l}$ using the same buffer. Identical concentrations $(2 \mu \mathrm{g})$ of the peptides were analyzed on a Q-Exactive Orbitrap mass spectrometer coupled to an Easy NanoLC-1000 system (Thermo Fisher Scientific). Each sample was analyzed in triplicate. Protein identification and label-free quantification (LFQ) were performed with MaxQuant software package $(18,19)$. Analysis of MS spectra was performed using the following parameters: acetylation of the protein $\mathrm{N}$-terminus and oxidation of methionine as variable modifications and carbamidomethylation of cysteine as fixed modification. UniProt-SwissProt human canonical database (version 2016, canonical proteome; 20198 identifiers) was selected as FASTA file. Seven amino acids were selected as minimum peptide length. Mass accuracy thresholds for the analysis were as follows: 15ppm for MS and 0.8 Da for MS/MS. Match between runs option was kept as default (match time window: $0.7 \mathrm{~min}$; alignment time window: $4 \mathrm{~min}$ ). LFQ was enabled and LFQ minimum ratio count was set to 1. Remaining options were kept as default. Only unique and razor peptides were used for identification and quantitation. Mascot was also used for database searches and identification (Matrix Science). Tandem mass MS2 spectra identifying and validating the peptides used for the validation of quantitation of each protein are displayed below in Figure 1. 
A.

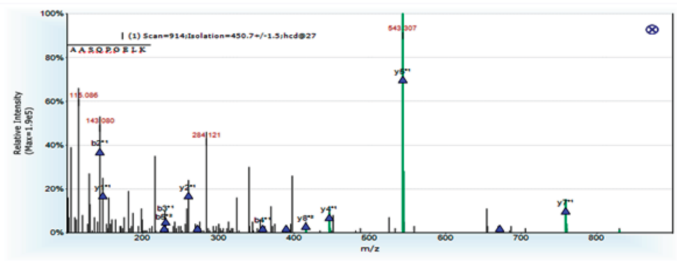

B.

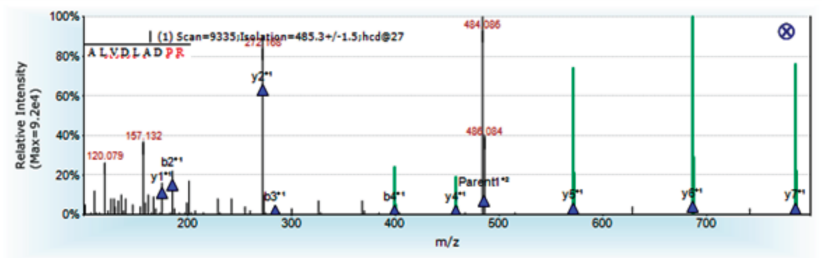

C.

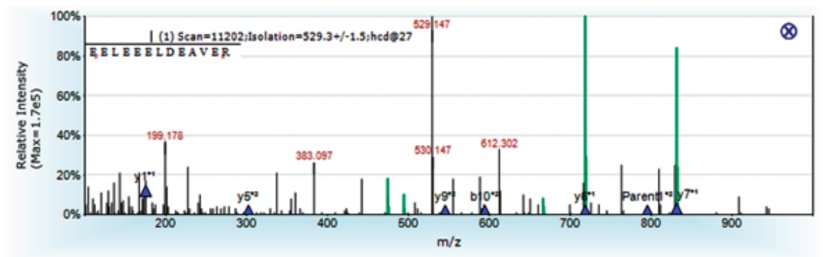

D.

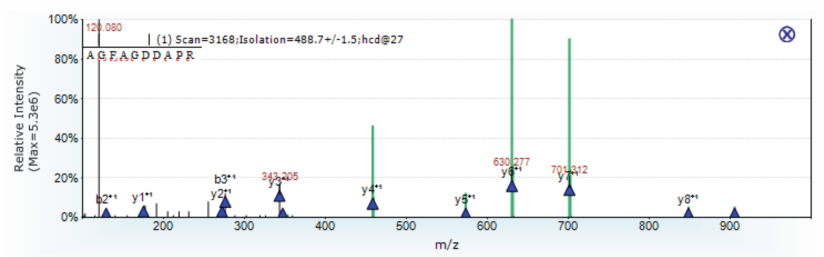

Figure 1. Tandem mass MS2 spectra identifying and validating the peptides used for the validation of quantitation of each protein in global islet proteomics analysis. A. Tandem mass spectra identifying and validating the peptide used for quantitation of carboxypeptidase $E$ (AASQPGELK). The corresponding y and $b$ ions are marked with blue triangles. The Mascot ion score for this peptide was 34 with an expect score of 0.0098. B. Tandem mass spectra identifying and validating the peptide used for quantitation of prohormone convertase $1 / 3$ (ALVDLADPR). The corresponding $y$ and $b$ ions are marked with blue triangles. The Mascot ion score for this peptide was 36 with an expect score of 0.0063 . C. Tandem mass spectra identifying and validating the peptide used for quantitation of prohormone convertase 2 (EELEEELDEAVER). The corresponding $y$ and $b$ ions are marked with blue triangles. The Mascot ion score for this peptide was 32 with an expect score of 0.012 . D. Tandem mass spectra identifying and validating the peptide used for quantitation of actin (AGFAGDDAPR). The corresponding $y$ and $b$ ions are marked with blue triangles. The Mascot ion score for this peptide was 70 with an expect score of 9.17E-7. 


\section{Statistics}

Analyses of cytokine treated islet data were performed using GraphPad Prism 7.0. A student's t-test was used to compare expression of proinsulin processing enzymes between control and cytokine treated islets.

For proteomic analyses, Perseus (version 1.5.2.6) was used to perform statistical analysis of LFQ proteomic data after $\log _{2}$ transformation, data imputation and filtration. Twosample t-tests were used together with permutation-based false discovery rate calculations for comparative quantitative analysis of protein expression in the two sample cohorts (T-test, $\mathrm{FDR}=0.05, p<0.05)$. This analysis takes into consideration all the peptides that are identified from the protein. Pinnacle, a quantitative proteomic analysis software (Optys Tech Corporation) was used for visualization and validation of the LFQ data using the areas under the curve from extracted ion chromatograms of precursor ions of unique peptides from targeted proteins. Pinnacle utilizes extracted ion chromatograms generated from the mass spectrometry MS1 data feature (peptides) and their corresponding MS2 fragmentation data to confirm the identity of the signal for each replicate sample. Peptides with the best ionization efficiencies, peak shape and isotopic fidelity were used for comparative analysis. Actin was used as an internal control. Unpaired t-tests were used to compare mean area under the curve values for each subject group. For all analyses, two-tailed $p$ values of $\leq 0.05$ were considered significant. 


\section{RESULTS}

To explore whether abnormalities in proinsulin processing were present in pancreatic tissue sections from 17 donors with type 1 diabetes from the nPOD collection, immunostaining was performed for insulin and proinsulin in pancreatic sections from nondiabetic control donors and donors characterized as having clinical type 1 diabetes (duration 1.5-28 years) with a wide range of demographic and clinical characteristics (Table 2). In control donors, the majority of $\beta$ cells exhibited both proinsulin and insulin staining with limited overlap observed between regions of proinsulin and insulin staining. Within our cohort of donors with T1D, $47 \%(n=8)$ lacked any detectable insulin and proinsulin staining. Among sections from donors with T1D with insulin positive cells, many sections exhibited scattered insulin positive cells or islets lacking central insulin positive cells. Although $55 \%(n=5)$ of these insulin positive sections exhibited a staining pattern where the majority of insulin $+\beta$-cells also stained positive for proinsulin, in 4 donors (Table 2, Figure 2; Case IDs 6040, 6069, 6243, and 6211), a different phenotype was seen where multiple proinsulin-enriched but insulin poor $\beta$-cells were observed. 
Table 2. Characteristics of nPOD Donor Staining

\begin{tabular}{|c|c|c|c|c|c|c|c|c|}
\hline $\begin{array}{l}\text { Case } \\
\text { ID }\end{array}$ & Age & $\begin{array}{l}\text { T1D } \\
\text { Duration } \\
\text { (years) }\end{array}$ & Sex & BMI & $\begin{array}{l}\text { Positive } \\
\text { aAbs }\end{array}$ & $\begin{array}{l}\text { Detectable } \\
\text { Fasting Serum } \\
\text { C-peptide }\end{array}$ & $\begin{array}{l}\text { Insulin + } \\
\text { Cells } \\
\text { Present }\end{array}$ & Proinsulin (PI) Staining Phenotype \\
\hline 6015 & 39 & n/a (Control) & $\mathrm{F}$ & 32.2 & $\mathrm{n} / \mathrm{a}$ & $\mathrm{n} / \mathrm{a}$ & + & Multiple costaining cells \\
\hline 6034 & 32 & n/a (Control) & $\mathrm{F}$ & 25.2 & $\mathrm{n} / \mathrm{a}$ & $\mathrm{n} / \mathrm{a}$ & + & Multiple costaining cells \\
\hline 6055 & 27 & n/a (Control) & $\mathrm{M}$ & 22.7 & $\mathrm{n} / \mathrm{a}$ & $\mathrm{n} / \mathrm{a}$ & + & Multiple costaining cells \\
\hline 6104 & 41 & n/a (Control) & $\mathrm{M}$ & 20.5 & $\mathrm{n} / \mathrm{a}$ & $\mathrm{n} / \mathrm{a}$ & + & Multiple costaining cells \\
\hline 6229 & 31 & n/a (Control) & $\mathrm{F}$ & 26.9 & $\mathrm{n} / \mathrm{a}$ & $\mathrm{n} / \mathrm{a}$ & + & Multiple costaining cells \\
\hline 6038 & 37.2 & 20 & $\mathrm{~F}$ & 30.9 & - & + & + & Multiple costaining cells \\
\hline 6041 & 26.3 & 23 & $\mathrm{M}$ & 28.4 & - & - & - & None \\
\hline 6054 & 35.1 & 30 & $\mathrm{~F}$ & 30.4 & mIAA & - & - & None \\
\hline 6077 & 32.9 & 19 & $\mathrm{~F}$ & 22 & mIAA & - & - & None \\
\hline 6141 & 36.7 & 28 & M & 26 & $\begin{array}{l}\text { mIAA, IA-2, } \\
\text { GAD, ZnT8 }\end{array}$ & - & - & None \\
\hline 6180 & 27.1 & 11 & $\mathrm{M}$ & 25.9 & $\begin{array}{l}\text { mIAA, IA-2, } \\
\text { GAD, ZnT8 }\end{array}$ & - & - & None \\
\hline 6208 & 32.6 & 16 & $\mathrm{~F}$ & 23.4 & - & - & - & None \\
\hline 6040 & 50 & 20 & $\mathrm{~F}$ & 31.6 & mIAA & - & + & $\begin{array}{l}\text { Pseudoatrophic islets with rare insulin+ } \\
\text { cells which were mostly PI-enriched, } \\
\text { insulin poor cells }\end{array}$ \\
\hline 6069 & 22.9 & 7 & M & 28.8 & Unknown & Unknown & + & $\begin{array}{l}\text { Mixed beta cell phenotype with some } \\
\text { islets displaying mostly costaining cells } \\
\text { and some islets with numerous PI- } \\
\text { enriched, insulin poor cells }\end{array}$ \\
\hline 6070 & 22.6 & 7 & $\mathrm{~F}$ & 21.6 & mIAA, IA-2 & - & + & Multiple costaining cells \\
\hline
\end{tabular}




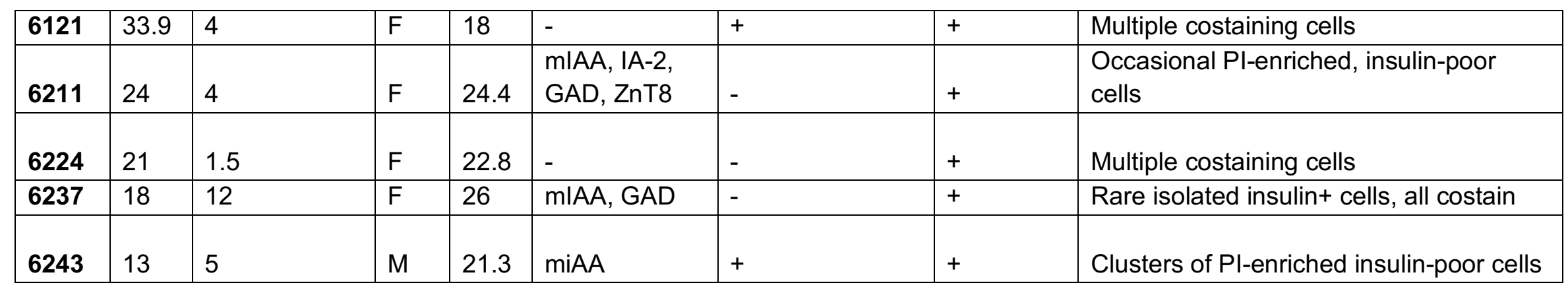

nPOD- Network for Pancreatic Organ Donors with Diabetes; T1D- Type 1 Diabetes Mellitus; BMI- Body Mass Index; aAbs-

autoantibodies; proinsulin-PI; miAA- microinsulin autoantibody; IA-2- islet antigen 2 antibody; GAD- glutamic acid decarboxylase antibody; ZnT8- zinc transporter 8 antibody 


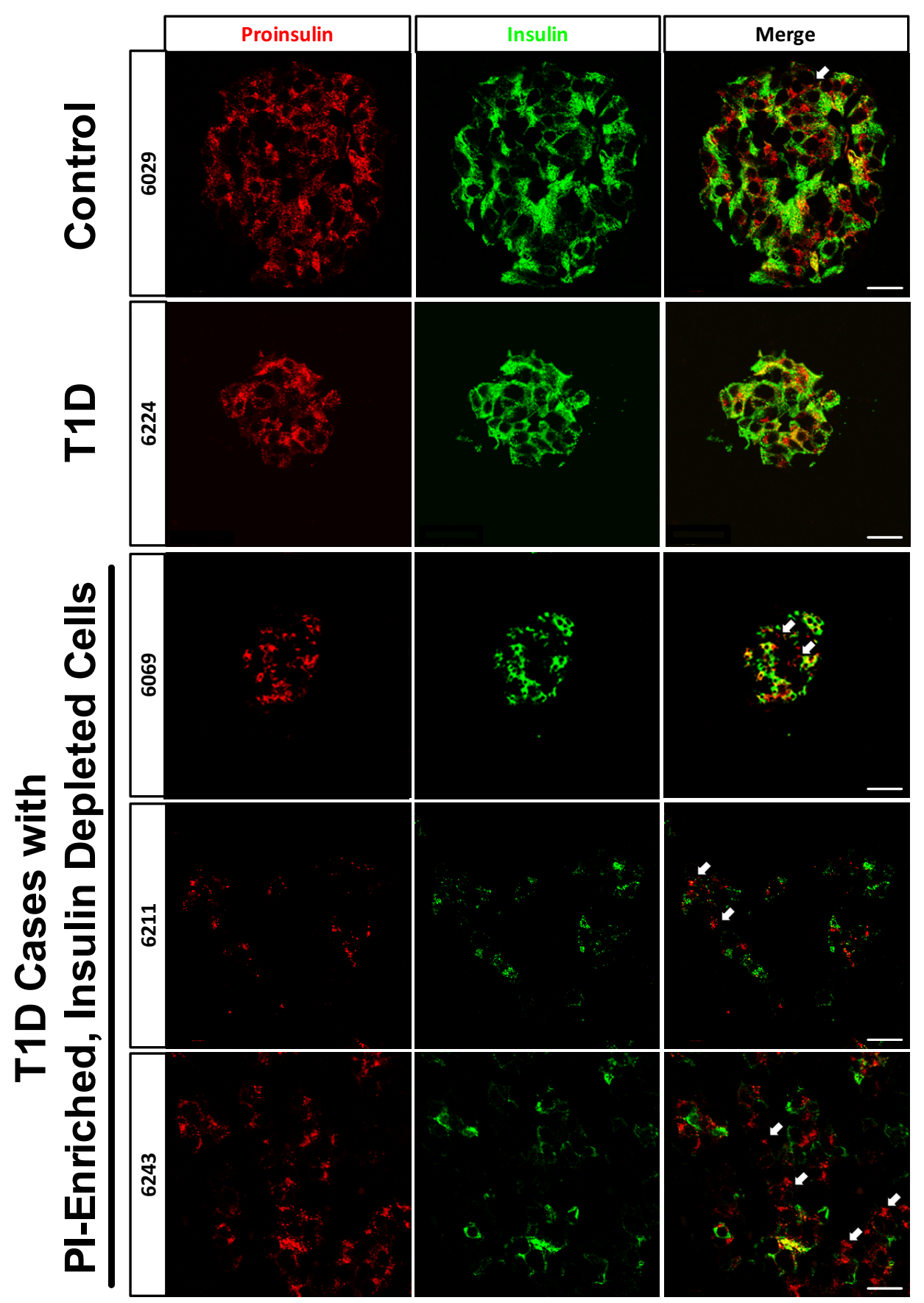

Figure 2: Examples of Proinsulin (PI) and Insulin Immunostaining Patterns in Type 1 Diabetes (T1D) Donor Islets. Immunostaining of proinsulin (green) and insulin (red) was performed on pancreata from non-diabetic control donors and 16 T1D donors. Staining from 3 donors exhibiting multiple Pl-enriched, and insulin depleted cells are shown (indicated by white arrows; case IDs 6069, 6243, 6211). These cells were rare in nondiabetic control donors. Scale bars represent $200 \mu \mathrm{m}$. 
To explore potential mechanisms of impaired prohormone processing, LCM followed by quantitative mass spectrometry analysis of proinsulin processing enzymes was performed on pancreatic sections from nPOD donors with type 1 diabetes compared to nondiabetic controls. Consistent with a reduction in proinsulin processing, LFQ analysis demonstrated significant reductions in CPE $(-3.20$ fold change, $p<0.001)$, as well as PC1/3 levels $(-1.66$ fold change, $p<0.001)$ in islets from donors with type 1 diabetes compared to controls. In contrast, there were no significant differences in expression levels of PC2 $(-0.442$ fold change; $p=0.368)$ or the control protein, actin $(-0.007$ fold change; $p=0.939)$, between the two groups. The area under the curve values from extracted ion chromatograms of the MS1 features of representative peptides from the target proteins are quantified in Figure 3A-E. Peptide scores for each of the four peptides were beyond the significance threshold in Mascot searches. Similar to the LFQ analysis, comparison of mean area under the curve values for control donors compared to donors with type 1 diabetes revealed a clear trend towards a reduction in CPE $(p=0.0514)$ and a significant reduction in PC1/3 ( $p=0.0046)$ (Figure 3B-C), but no differences in PC2 or actin expression (Figure 3D-E). 
A Control Donors T1D Donors

$\underline{6271} \quad \underline{6234} \quad \underline{6238} \quad \underline{6247} \quad \underline{6212} \quad \underline{6245}$

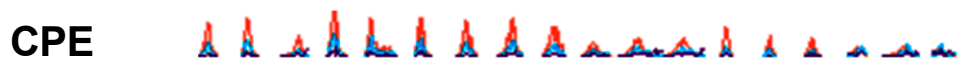

PC 1/3

PC 2 \& $1 \times \ldots \ldots \ldots$

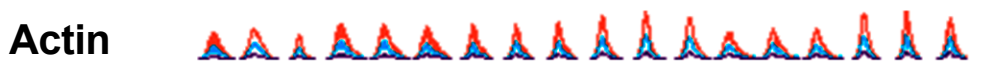

B.

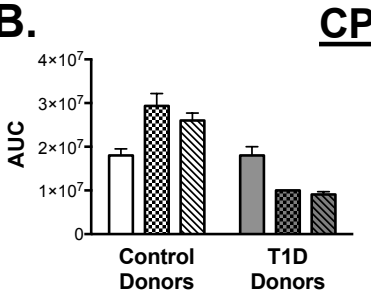

D.

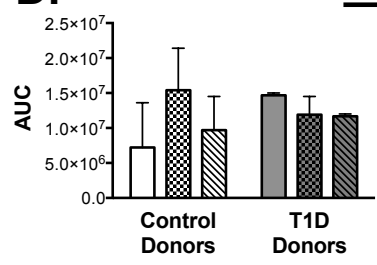

$\underline{\mathrm{PC} 2}$

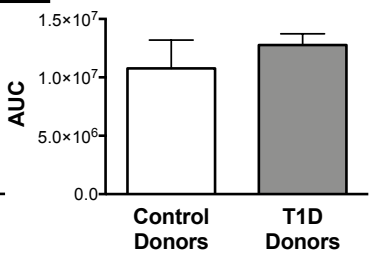

C.

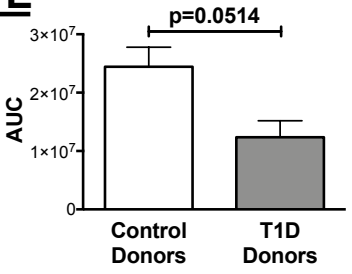

E.

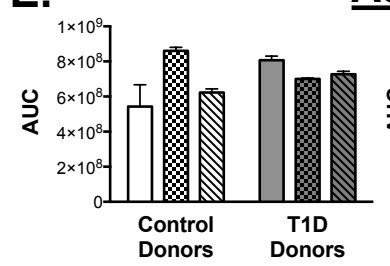

$\underline{P C 1 / 3}$
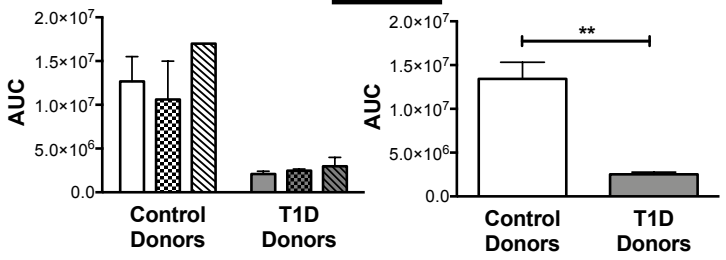

Actin

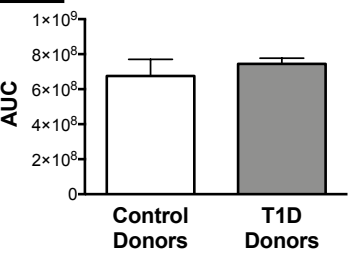

Figure 3. Expression of CPE, PC1/3 and PC2 in LCM islets from nondiabetic controls and donors with type 1 diabetes (T1D). A. Extracted ion chromatograms of peptides from nondiabetic individuals $(n=3)$ compared to T1D donors $(n=3)$ with sequences AASQPGELK, ALVDLADPR, EELEEELDEAVER and AGFAGDDAPR from CPE, PC1/3, PC2, and actin, respectively. The Mascot identification ion and expect scores were significant for each of the four peptides. Expression of the individual peptides in each nPOD case (run as triplicates) are shown. nPOD case IDs are indicated above each set of triplicates. B-E: Quantitation of area under the curve (AUC) for chromatograms from each peptide is shown for each donor on the left, as well as in aggregate form on the right, with means and standard errors indicated. Aggregate means of control donors were compared to donors with type 1 diabetes using an unpaired t-test. $(n=3) ;{ }^{* *} p<0.01$ CPE-carboxypeptidase E; PC1/3- prohormone convertase 1/3; PC2- prohormone convertase 2. 
To test whether reductions in islet proinsulin processing enzyme expression may be associated with islet inflammatory stress, we assayed expression of CPE, PC1/3, and PC2 in human islets from ten donors that were treated with 24 hours of a cytokine cocktail $(50 \mathrm{U} / \mathrm{ml} \mathrm{IL}-$ $1 \beta$ and $1000 \mathrm{U} / \mathrm{ml}$ INF- $\mathrm{\gamma}$ ) for 24 hours. As shown in Figure 4, cytokine treatment was associated with significant reductions in mRNA expression for each of the processing enzymes.

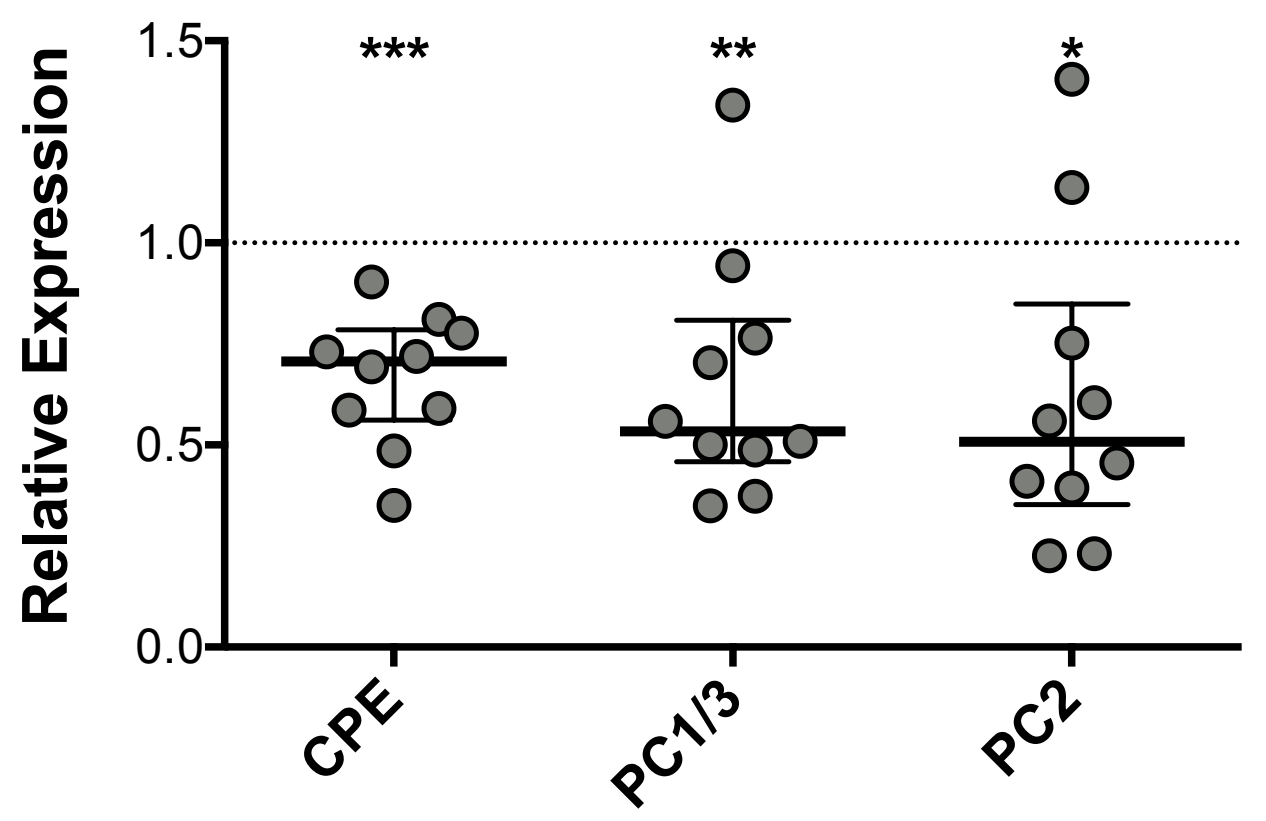

Figure 4. Islet Inflammatory Stress is associated with reductions in proinsulin processing enzyme expression. qRT-PCR for Carboxypeptidase E (CPE), Prohormone Convertase 1/3 (PC1/3), and Prohormone Convertase 2 (PC2) was performed in human islets treated with or without an inflammatory cytokine cocktail consisting of of IL-1 $13(50 \mathrm{U} / \mathrm{ml})$ and INF-y $(1000 \mathrm{U} / \mathrm{ml})$ for 24 hours. Bars shown represent median $+/$ - interquartile range of mRNA expression relative to untreated islets from the same donor (indicated by the dashed line). $N=10 ;{ }^{*} p<0.05 ;{ }^{* *} p<0.01$; ${ }^{* * *} p<0.001$ 


\section{DISCUSSION}

We recently reported that the ability to initiate preproinsulin production and secrete proinsulin persists in most individuals with longstanding type 1 diabetes, even in those who were functionally C-peptide negative. Moreover, analysis of longitudinal data from $>90$ individuals with T1D of $\geq 3$ years duration showed that serum proinsulin levels remained fairly stable over four years of follow-up (11). Here, we show for the first time immunostaining data that identifies a discordance between proinsulin production and conversion to mature insulin within islets of a subset of individuals with established type 1 diabetes, as well as proteomic analysis suggesting that this discordance is correlated with a reduction in the protein expression level of PC1/3 and CPE in islets from type donors with 1 diabetes. These data may help to explain at a mechanistic level the deficiency of C-peptide (and insulin) from individuals that are otherwise proinsulin-positive.

The accumulation of incompletely processed proinsulin in longstanding T1D demonstrates a clearly disturbed environment for proinsulin maturation, a process normally regulated by the processing enzymes, $\mathrm{PC} 1 / 3,2$, and $\mathrm{CPE}(8)$. A previous proteomic analysis of whole pancreas tissue lysates from diabetic donors reported a 10-fold decrease in CPE expression compared to nondiabetic donors (20). Our LCM analysis extends this observation by showing that reductions in the expression of proinsulin processing enzymes are specific to islets in individuals with T1D. Although loss of $\beta$-cell mass itself could lead to an absolute reduction in proinsulin processing enzymes, in our study LCM analysis was only performed on islets that contained insulin. This, in combination with the observation that cytokine stress directly lowers the expression of mRNAs encoding prohormone processing enzymes in human islets, provides an additional (alternative, although not mutually exclusive) explanation for our findings. Prohormone convertase and CPE activities are also involved in proamylin processing, and evidence of altered pro islet amyloid polypeptide processing has also been identified in patients with type 1 diabetes, which lends further credence to our observations $(21,22)$. 
Regarding our in vitro data suggesting that diminished proinsulin processing enzyme expression may be, at least in part, associated with islet inflammatory stress during T1D, we recognize that the etiology of these observations could be multifactorial. For one, prior reports have described increased proinsulin release and decreased PC1/3 and PC2 protein in human islets treated with inflammatory cytokines (23). Enzyme expression and/or activity could be also impacted by hyperglycemia or other extrinsic factors, as well as cell intrinsic factors such as activation of ER stress, a pathway increasingly implicated in type 1 diabetes pathogenesis (24, 25). Along these lines, reduced expression, translation, and posttranslational processing of CPE and PC1/3 have been previously been reported in ex vivo models of ER stress in human islets (26-28). Alternatively, CPE has been identified previously as an islet autoantigen (29), and we cannot exclude that autoimmune targeting of processing enzymes could lead to altered expression and/or activity of these enzymes. Altered prohormone processing could also represent an inherited phenotype that is present at baseline in some subjects who go on to develop type 1 diabetes, potentially exacerbating progression of the disease. Consistent with this model, polymorphisms near the gene locus encoding CPE have been linked to T1D susceptibility (30).

The increasing identification of persistent $\beta$ cells in long-duration T1D raises a number of questions regarding the source of these cells and how their molecular phenotype intersects with ambient states of immune activation. To date, analysis of persistent $\beta$ cells in sections from donors with long-duration T1D using confocal microscopy has not provided strong evidence for $\beta$ cell replication or neogenesis (7). Key unanswered questions are whether these persistent $\beta$ cells represent de-differentiated $\beta$ cells and whether the process of de-differentiation may enable $\beta$ cells to escape immune recognition. In this regard, a subset of $\beta$ cells with reduced immunogenicity was identified in the non-obese diabetic (NOD) mouse model of T1D. These cells had reduced insulin content and reduced expression of genes associated with $\beta$ cell identity, whilst genes associated with immune modulation and "stemness" were increased (31). 
Interestingly, $\beta$-cell dedifferentiation due to transcription factor FoxO1 deletion in mouse models has also been linked also to dramatic reductions in the expression of proinsulin processing enzymes (32). The recent observation that many islets in pancreatic sections from individuals with longstanding T1D harbor very low level insulin content in association with identity markers for both $\beta$ cells and other islet cells also supports the possibility of dedifferentiated islet cells in longstanding T1D (33). Taken together, our results and the above published findings suggest potential associations between altered proinsulin processing, loss of prohormone processing enzyme expression, and $\beta$-cell identity (32). However, additional work is needed in human samples to fully elucidate these relationships.

In summary, our findings demonstrate that persistent circulating proinsulin in individuals with longstanding type 1 diabetes could be related to altered proinsulin processing at the level of the islet, which is exacerbated by islet inflammatory stress. These findings present the tantalizing proposition that such residual proinsulin producing cells are "sleeping" and could potentially be amenable to a therapeutic strategy repairing the processing deficit and "waking" the cells. Along these lines, our data suggest that, in longstanding type 1 diabetes, measurement of proinsulin in addition to C-peptide may provide a more sensitive indicator of persistent $\beta$-cell mass than measurement of C-peptide alone. Future work is needed to fully characterize the molecular phenotype of these persistent $\beta$ cells and to delineate whether therapeutics targeting proinsulin processing could increase endogenous insulin production in type 1 diabetes.

\section{ACKNOWLEDGMENTS}

None of the authors have any relevant conflicts of interest to disclose. E.S. and C.E.M serve as guarantors of this work.

A portion of this research was performed with the support of the Network for Pancreatic Organ Donors with Diabetes (nPOD), a collaborative type 1 diabetes research project 
sponsored by JDRF. Organ Procurement Organizations (OPO) partnering with nPOD to provide research resources are listed at http://www.jdrfnpod.org/for-partners/npod-partners/. We also acknowledge Wojciech Grzesik for technical assistance with proinsulin measurement and LCM capture.

Other Funding Sources: This manuscript was supported by funding from NIDDK K08DK103983 to E.K.S., a Pediatric Endocrine Society Clinical Scholar Award to E.K.S., and NIH grants R01 DK093954 (to C.E-M.) R01 DK48280 (to P.A) and UC4 DK 104166 (to C.E-M. and R.G.M.), VA Merit Award I01BX001733 (to C.E-M.), JDRF Pioneer Award and Strategic Research Agreement (to C.E-M.), JDRF 47-2014-299-Q-R (C.E-M.), and JDRF grant number 2SRA-2017-498-M-B (to E.K.S). 


\section{REFERENCES}

1. DiMeglio LA, Evans-Molina C, Oram RA. Type 1 diabetes. Lancet. 2018;391(10138):2449-62.

2. Davis AK, DuBose SN, Haller MJ, Miller KM, DiMeglio LA, Bethin KE, et al. Prevalence of Detectable C-Peptide According to Age at Diagnosis and Duration of Type 1 Diabetes. Diabetes Care. 2015;38(3):476-81.

3. Oram RA, Jones AG, Besser RE, Knight BA, Shields BM, Brown RJ, et al. The majority of patients with long-duration type 1 diabetes are insulin microsecretors and have functioning beta cells. Diabetologia. 2014;57(1):187-91.

4. Oram RA, McDonald TJ, Shields BM, Hudson MM, Shepherd MH, Hammersley S, et al. Most people with long-duration type 1 diabetes in a large population-based study are insulin microsecretors. Diabetes Care. 2015;38(2):323-8.

5. Keenan HA, Sun JK, Levine J, Doria A, Aiello LP, Eisenbarth G, et al. Residual insulin production and pancreatic ss-cell turnover after 50 years of diabetes: Joslin Medalist Study. Diabetes. 2010;59(11):2846-53.

6. Campbell-Thompson M, Fu A, Kaddis JS, Wasserfall C, Schatz DA, Pugliese A, et al. Insulitis and beta-Cell Mass in the Natural History of Type 1 Diabetes. Diabetes. 2016;65(3):719-31.

7. Lam CJ, Jacobson DR, Rankin MM, Cox AR, Kushner JA. beta Cells Persist in T1D Pancreata Without Evidence of Ongoing beta-Cell Turnover or Neogenesis. J Clin Endocrinol Metab. 2017;102(8):2647-59.

8. Liu M, Wright J, Guo H, Xiong Y, Arvan P. Proinsulin entry and transit through the endoplasmic reticulum in pancreatic beta cells. Vitam Horm. 2014;95:35-62.

9. Eizirik DL, Miani M, Cardozo AK. Signalling danger: endoplasmic reticulum stress and the unfolded protein response in pancreatic islet inflammation. Diabetologia. 2013;56(2):234-41. 10. Tersey SA, Nishiki Y, Templin AT, Cabrera SM, Stull ND, Colvin SC, et al. Islet beta-cell endoplasmic reticulum stress precedes the onset of type 1 diabetes in the nonobese diabetic mouse model. Diabetes. 2012;61(4):818-27.

11. Sims EK, Bahnson HT, Nyalwidhe J, Haataja L, Davis AK, Speake C, et al. Proinsulin Secretion is a Persistent Feature of Type 1 Diabetes. Diabetes care. 2018.

12. Campbell-Thompson M, Wasserfall C, Kaddis J, Albanese-O'Neill A, Staeva T, Nierras C, et al. Network for Pancreatic Organ Donors with Diabetes (nPOD): developing a tissue biobank for type 1 diabetes. Diabetes Metab Res Rev. 2012;28(7):608-17.

13. Asadi A, Bruin JE, Kieffer TJ. Characterization of antibodies to products of proinsulin processing using immunofluorescence staining of pancreas in multiple species. Journal of Histochemistry \& Cytochemistry. 2015;63(8):646-62.

14. Mastracci TL, Anderson KR, Papizan JB, Sussel L. Regulation of Neurod1 contributes to the lineage potential of Neurogenin3+ endocrine precursor cells in the pancreas. PLoS Genet. 2013;9(2):e1003278.

15. Nyalwidhe JO, Grzesik WJ, Burch TC, Semeraro ML, Waseem T, Gerling IC, et al. Comparative quantitative proteomic analysis of disease stratified laser captured microdissected human islets identifies proteins and pathways potentially related to type 1 diabetes. PLoS One. 2017;12(9):e0183908.

16. Van De Winkel M, Pipeleers D. Autofluorescence-activated cell sorting of pancreatic islet cells: purification of insulin-containing B-cells according to glucose-induced changes in cellular redox state. Biochemical and biophysical research communications. 1983;114(2):835-42.

17. Croce A, Bottiroli G. New light in flavin autofluorescence. European Journal of Histochemistry. 2015;59(4). 
18. Cox J, Mann M. MaxQuant enables high peptide identification rates, individualized p.p.b.-range mass accuracies and proteome-wide protein quantification. Nat Biotechnol. 2008;26(12):1367-72.

19. Luber CA, Cox J, Lauterbach H, Fancke B, Selbach M, Tschopp J, et al. Quantitative proteomics reveals subset-specific viral recognition in dendritic cells. Immunity. 2010;32(2):27989.

20. Burch TC, Morris MA, Campbell-Thompson M, Pugliese A, Nadler JL, Nyalwidhe JO. Proteomic Analysis of Disease Stratified Human Pancreas Tissue Indicates Unique Signature of Type 1 Diabetes. PLoS One. 2015;10(8):e0135663.

21. Yonemoto IT, Kroon GJ, Dyson HJ, Balch WE, Kelly JW. Amylin proprotein processing generates progressively more amyloidogenic peptides that initially sample the helical state. Biochemistry. 2008;47(37):9900-10.

22. Courtade JA, Klimek-Abercrombie AM, Chen YC, Patel N, Lu PY, Speake C, et al. Measurement of pro-islet amyloid polypeptide (1-48) in diabetes and islet transplants. J Clin Endocrinol Metab. 2017.

23. Hostens K, Pavlovic D, Zambre Y, Ling Z, Van Schravendijk C, Eizirik DL, et al. Exposure of human islets to cytokines can result in disproportionately elevated proinsulin release. J Clin Invest. 1999;104(1):67-72.

24. Stull ND, Breite A, McCarthy R, Tersey SA, Mirmira RG. Mouse islet of Langerhans isolation using a combination of purified collagenase and neutral protease. JoVE (Journal of Visualized Experiments). 2012(67):e4137-e.

25. Marhfour I, Lopez XM, Lefkaditis D, Salmon I, Allagnat F, Richardson SJ, et al. Expression of endoplasmic reticulum stress markers in the islets of patients with type 1 diabetes. Diabetologia. 2012;55(9):2417-20.

26. Jeffrey KD, Alejandro EU, Luciani DS, Kalynyak TB, Hu X, Li H, et al. Carboxypeptidase E mediates palmitate-induced beta-cell ER stress and apoptosis. Proc Natl Acad Sci U S A. 2008;105(24):8452-7.

27. Pirot P, Naamane N, Libert F, Magnusson NE, Orntoft TF, Cardozo AK, et al. Global profiling of genes modified by endoplasmic reticulum stress in pancreatic beta cells reveals the early degradation of insulin mRNAs. Diabetologia. 2007;50(5):1006-14.

28. Furukawa H, Carroll RJ, Swift HH, Steiner DF. Long-term elevation of free fatty acids leads to delayed processing of proinsulin and prohormone convertases 2 and 3 in the pancreatic beta-cell line MIN6. Diabetes. 1999;48(7):1395-401.

29. Castano L, Russo E, Zhou L, Lipes MA, Eisenbarth GS. Identification and cloning of a granule autoantigen (carboxypeptidase-H) associated with type I diabetes. J Clin Endocrinol Metab. 1991;73(6):1197-201.

30. Onengut-Gumuscu S, Chen WM, Burren O, Cooper NJ, Quinlan AR, Mychaleckyj JC, et al. Fine mapping of type 1 diabetes susceptibility loci and evidence for colocalization of causal variants with lymphoid gene enhancers. Nat Genet. 2015;47(4):381-6.

31. Rui J, Deng S, Arazi A, Perdigoto AL, Liu Z, Herold KC. beta Cells that Resist Immunological Attack Develop during Progression of Autoimmune Diabetes in NOD Mice. Cell Metab. 2017;25(3):727-38.

32. Talchai C, Xuan S, Lin HV, Sussel L, Accili D. Pancreatic beta cell dedifferentiation as a mechanism of diabetic beta cell failure. Cell. 2012;150(6):1223-34.

33. Lam CJ, Chatterjee A, Shen E, Cox AR, Kushner JA. Low Level Insulin Content Within Abundant Non-Beta Islet Endocrine Cells in Long-Standing Type 1 Diabetes. Diabetes. 2018. 
bioRxiv preprint doi: https://doi.org/10.1101/542027; this version posted February 8, 2019. The copyright holder for this preprint (which was not certified by peer review) is the author/funder, who has granted bioRxiv a license to display the preprint in perpetuity. It is made available under aCC-BY-NC-ND 4.0 International license. 